\title{
THE SHEAR STRENGTH OF THE ROUND CLINCHING JOINTS FORMED BY USING EXTENSIBLE DIES
}

\author{
Waldemar Witkowski ${ }^{1}$ \\ 1 Rzeszow University ofTechnology, PowstańcówWarszawy 12,35-959Rzeszów, Poland, e-mail:wwitkowski@ \\ prz.edu.pl
}

Received: 2015.04 .06 Accepted: 2015.05.08 Published: 2015.06.01

\begin{abstract}
The clinching joining technology is one of the most popular joining technologies by redrawing sheet material. The joining process parameters, the sheet material and its arrangements influences joints' strength. Cylindrical axial-symmetrical joints formed by using rigid die and punch are still developed. The change of the rigid die on the die with movable segments affect the forming process and joint strength parameters. So there is a need to do experimental researches of the possibilities of joint formation by unchanged punch geometry and different die shape. In this article the forming process parameters (forming force, process energy consumption and its standard deviations) and joints strength parameters (maximum shearing force, total dissipated energy and dissipated energy up to 0.3 maximum force), according to the ISO 12996 standard, for the joints formed with using die with 2, 3 and 4 movable segments were presented. The punch geometry was unchanged and the minimum thickness of the embossment was also unchanged. For the die with 2 and 4 segments the load force direction influence on the joints strength was also presented.
\end{abstract}

Keywords: sheet metal joining by redrawing, ISO 12996, joints strength,

\section{INTRODUCTION}

Development of new material used in the engineering design, especially in automotive industry, in household equipment industry or in aircraft industry, cause the right choice of the appropriate joining methods. Classical joining methods such as welding, soldering or temporary fastening cannot be always implemented to join modern materials. Therefore, alternative joining technologies are still being developed. One of such method is joining by pressing the materials. This technology, depending on the tools shape, use of additional fastener has many variations. The most common type of variations is joining by redrawing sheet without any additional fastener (clinching - CL) formed by using solid tools with axissymmetrical shape. This shape of tools provides isotropic properties of the joint $[1,2,3]$.

The basic geometry of the forming tools includes: punch diameter, diameter and depth of the die, the radius of the punch and die and the angle of inclination of the punch and die. These dimensions affect the proper formation and the joints strength. For different joined materials, its arrangement and thicknesses the tools geometry should be selected separately. The basic parameter of the joint is the minimum thickness of the joints embossment $(\mathrm{X})$, which determines the properly joint formation. Too low value of the parameter X causes that the material of the upper sheet lose its coherence in the bottom sheet. Too large value of $\mathrm{X}$ causes the interlock is formed not properly. The influence of the parameter $\mathrm{X}$ and punch diameter on the joints strength was presented in [4].

Numerical researches involving the forming process and the strength of the joints made by pressing $[5,6,7]$ represent a large contribution to the joints technology development. The determination of the tools geometry for the different material their thickness and its arrangement cause 
an increase in the use of computer simulation of forming process in order to reduce experimental studies $[8,9,10]$. The experimental research are usually related to the joints strength in shearing and tension test $[11,12]$. Some publications present results of the joints strength in multi-axis load state $[4,13]$, because the joint in real constructions need to carry the load different than shear or tear force.

The change of the shape and geometry of the die, with the punch unchanged, affecting the joint forming process and the joints strength. Influence the sheet thickness and forming force on the interlock shape and size of clinching and hybrid (clinching and glue) joints formed by using the die with three movable segments was presented in $[14,15]$. However, there is no publication about the influence of the number of movable segments of the die and the load direction related to the die segments on the joints strength in shearing test.

In this publication an experimental analysis of the clinching joints strength was presented. The joints were made by using the unchanged punch and different dies with movable segments (2, 3 and 4 segments). The influence of the force load direction related to the segments direction was presented. To compare the joints made by using different number of movable segments of the die the joints parameters, according to the ISO 12996 standard [16], were used.

\section{EXPERIMENTAL RESEARCH}

For the experimental research the DX51D+Z/275 (mat. number 1.0226) sheet material was used. The thickness of the samples was $1 \pm 0.05 \mathrm{~mm}$. Basic mechanical properties of the sheet material are:

- elastic modulus (Young's mod.) $E=210000 \mathrm{MPa}$,

- the yield strength $R_{p 0.2}=175 \mathrm{MPa}$,

- the tensile strength $R_{m}=375 \mathrm{MPa}$,

- elongation of $80 \mathrm{~mm}^{m} A_{80}=32 \%$,

- the coefficient of lateral constrictions (Poisson's ratio) $v=0.3$.

The chemical composition of the steel and maximum content in \% is: $\mathrm{C}(0.1), \mathrm{Mn}(0.7) \mathrm{P}$ (0.1), Ti (0.06), S (0.035), Al (0.025), N (0.01), $\mathrm{Fe}$ (other).

The lap joints were performed in the Pressed Joint Laboratory of the Department of Mechanical Engineering at Rzeszow University of Tech- nology. The press frame, with electric drive type EMPK, manufactured by ToxPressotechnik company was used [17]. The accuracy of the punch positioning in relation to the die was $0.01 \mathrm{~mm}$, and maximum forming force was set to $100 \mathrm{kN}$. The measuring and recording of the forming force as function of the punch displacement, with accuracy of $0.5 \%$ of the forming force, was enabled by force control systems of the press. The technological parameters of the forming process were chosen in accordance to the recommendation of the press manufacturer [18]. Measuring and recording of the forming force was carried out only in the forming step with punch speed $V=3 \mathrm{~mm} / \mathrm{s}$, until the parameter $X$ was reached. The minimal thickness of the embossment $(X)$ was set up to a value $0.5 \mathrm{~mm}$ ( $25 \%$ of total thickness of joined sheets). The real value of parameter $X$ was measured by using Mitutoyo digital calipers with measurement accuracy of $0.01 \mathrm{~mm}$ in range of $20 \mathrm{~mm}$. The punch diameter was $5.6 \mathrm{~mm}$.

The dies with movable segments were designed and manufactured to ensure the interlock forming without losing coherence of sheet material. The die depth was $1.4 \mathrm{~mm}$, and the outer joint diameter of the embossment was 8 mm (Fig. 1).

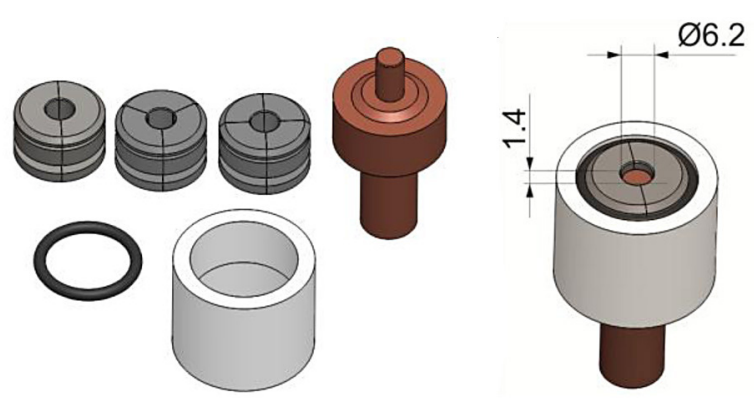

Fig. 1. CAD models of forming tools

The sheets samples with the length of 110 $\mathrm{mm}$, width $40 \mathrm{~mm}$ and $1 \mathrm{~mm}$ thickness were joined in five samples for each type of die and force load direction. The length of the overlapping elements was $40 \mathrm{~mm}$. In Figure 2 the load force directions were presented for each type of dies.

Static strength test for lap joints were carried out in accordance with guideline set in ISO 12996 standard. Shear tests were performed on UTS 100 testing machine equipped with the extensometer system (the measuring calipers were placed 20 $\mathrm{mm}$ from the joint, Figure 3). 

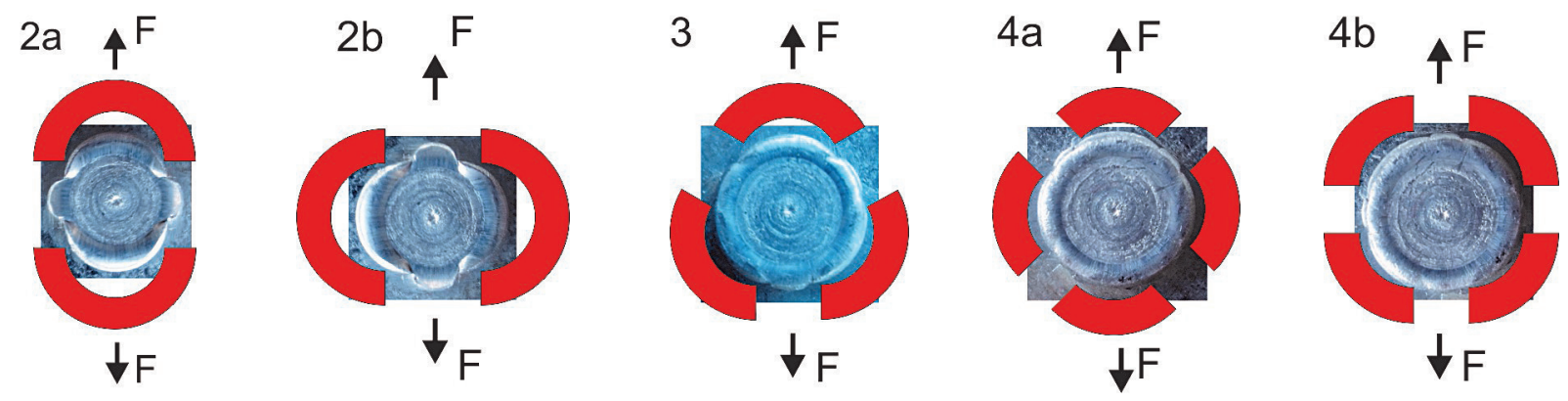

Fig. 2. Directions of load force in accordance to the die segments and samples nomenclature

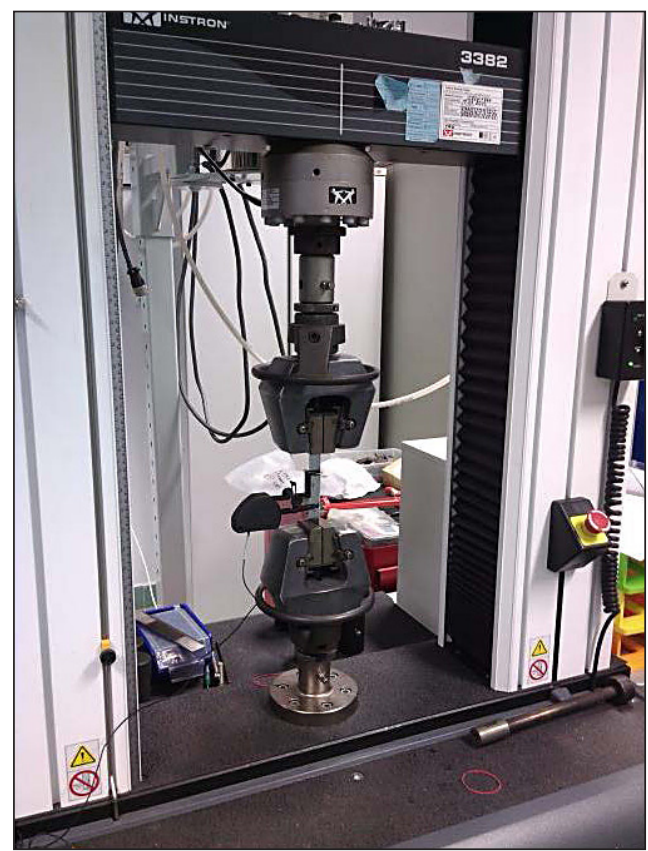

Fig. 3. UTS 100 testing machine with extensometer system

\section{RESULTS AND ANALYSIS}

During the joint forming the force-displacement curves of the punch were recorded. The average of the forming energy and the forming force with their standard deviations were calculated (Fig. 4). For all dies there was no difference in forming process. There was no crack in the cylindrical part of the embossment. The number of movable segments does not significantly affect the forming force and forming energy.

The lap joint samples joined with parameter $X=0.5 \mathrm{~mm}$, were tested in shearing test. The joints were destructed by losing sheet material coherence in cylindrical part of the interlock. There were no samples with partial coherence loosing and pulling out form the bottom sheet.

The main parameters of the joint strength is the maximum load force $\left(F_{\max }\right)$. The value of this force was different for all die variants. In ISO 12996 standard other parameters characterizing the joint strength were given, such as: total dissipated energy $(E)$, dissipated energy up to 0.3 maximum force $\left(E_{0.3 F \max }\right)$, dissipated energy up to maximum force $\left(E_{F \max }\right)$, displacement up to fracture $\left(s_{t}\right)$, displacement up to 0.3 maximum force $\left(s_{0.3 F \max }\right)$ and displacement up to maximum force $\left(s_{\text {Fmax }}\right)$, stiffness in elastic range, elastic load limit and others (Fig. 5). The values of some of the joint parameters were presented in Table 1.

The lap joint separation was not observed at maximum value of the shear force. After achiev-

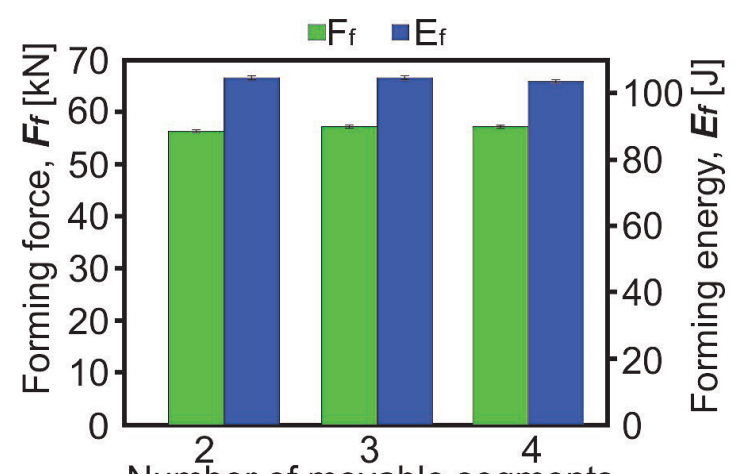

Number of movable segments

Fig. 4. Forming force and process energy consumption of clinching joining technology with using extensible die

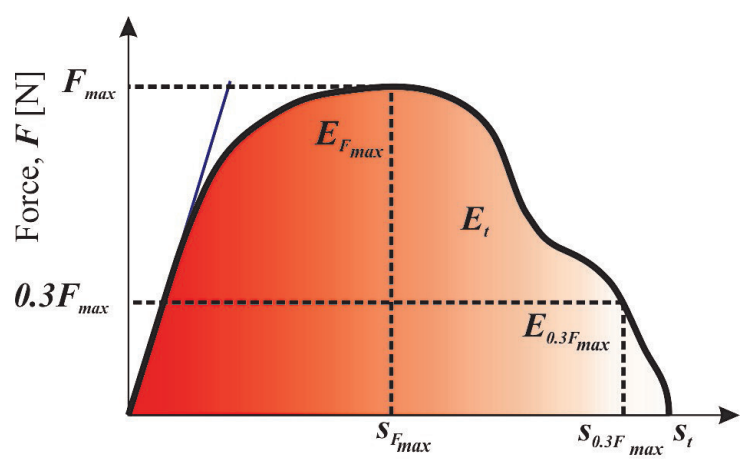

Displacement, $s$ [mm]

Fig. 5. Force-displacement curve and the joint parameters according to the ISO 12996 standard 
Table 1. Joints parameters according to the ISO 12996 standard

\begin{tabular}{|c|c|c|c|c|}
\hline $\begin{array}{c}\text { Movable segments } \\
\text { die configuration }\end{array}$ & $\begin{array}{c}\text { Maximum shearing force } \\
\mathbf{F}_{\max }[\mathrm{N}]\end{array}$ & $\begin{array}{c}\text { Dissipated energy up to 0.3 maximum } \\
\text { force }\left(\mathrm{F}=0.3 \mathrm{~F}_{\max }\right) \mathbf{E}_{0.3 \mathrm{max}}[\mathrm{J}]\end{array}$ & $\begin{array}{c}\text { Total dissipated } \\
\text { energy } \mathbf{E}_{\max }[\mathrm{J}]\end{array}$ & $\mathbf{E}_{\text {0.3Fmax }} / \mathbf{E}_{\max }(\%)$ \\
\hline $2 \mathrm{a}$ & 2745 & 1.354 & 3.371 & 0.402 \\
\hline $2 \mathrm{~b}$ & 2731 & 1.328 & 3.294 & 0.403 \\
\hline 3 & 3112 & 2.019 & 4.705 & 0.429 \\
\hline $4 a$ & 3228 & 2.031 & 4.411 & 0.440 \\
\hline 4b & 3186 & 1.907 & 4.351 & 0.438 \\
\hline
\end{tabular}

ing maximum shear force the shear test was continued until completely lap separation. The displacement for maximum shearing force ratio to the displacement until completely separation was $78,77 \%, 83 \%, 65 \%, 68 \%$ (for the die arrangements: $2 \mathrm{a}, 2 \mathrm{~b}, 3,4 \mathrm{a}, 4 \mathrm{~b})$. The changing of the load force direction for the die with 2 and 4 movable segments did not affect the joint strength and the joint strength parameter.

The shape and the dimension of the interlock determines whether the joint was formed properly (without any crack and sheet material coherence loosing). The changing of the number of the movable segments of die, in relation to unchanged punch geometry and value of parameter $X$, was to demonstrate that the interlock can be formed for each used die. The correct shape of interlock resembles the letter $S$. During the joint formation with using the die with movable segments these segments move radially and diverge. The sheet material fill the space between segments and cylindrical part of the die and also between each segment. So the interlock has a different shape and dimensions $\left(t_{s}\right.$ - dimension of the interlock in bottom sheet and $t_{n}$ - dimension of the interlock in upper sheet) depending on the joint cross-section. In Figure 6 on the left side is shape of interlock formed between the movable segment and cylindrical part of the die, and on right side the interlock is formed between two movable segments and cylindrical part of the die.

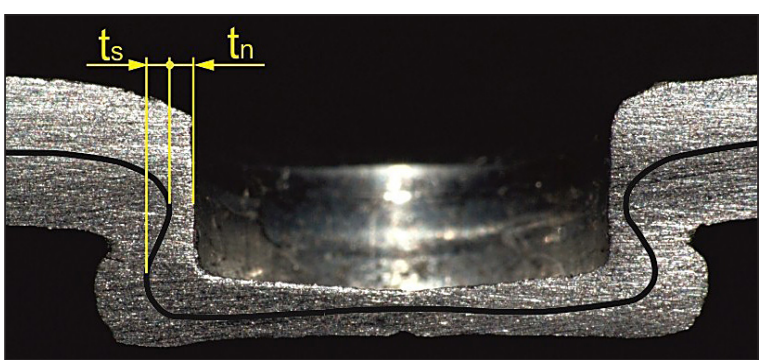

Fig. 6. The interlock cross-section of the joint formed by using the die with 3 movable segments
For the die with 3 movable segments the loading force was directed through the interlock with two different shapes and dimensions. For other die segments configuration of the force was directed by interlock with the same shape (between segment and die or between two segments and die).

\section{CONCLUSION}

The experimental researches were carried out to present the possibilities of the clinching joint formation with using unchanged punch geometry, the value of parameter $X$ and different number of die movable segments. For all die the interlock was formed properly without any crack und material failure. The joint forming parameters and the joint strength were presented. The forming process energy consumption and forming force had a high repeatability for all dies. The number of the movable segments did not significantly affect on the forming process and its parameters (energy consumption and forming force). The load force direction in the shear test did not also affect the joint strength. The interlock shape was not axiallysymmetrical because the sheet material flow, not only between the segment and the cylindrical part of the die, but also between the movable segments.

\section{REFERENCES}

1. Mori K., Bay N., Fratini L., Micari F., Tekkaya E.: Joining by plastic deformation. CIRP Annals - Manufacturing Technology, 62, 2013, 673-694.

2. Mucha J.: Współczesne techniki łączenia cienkich blach - zaciskanie przez wytłaczanie (Clinching). Mechanik, 80, 2007, 932-939.

3. Mucha J., Bartczak B., Analiza przetłoczeniowego łączenia blach. Archiwum Technologii Maszyn i Automatyzacji, 3/31, 2011, 59-68.

4. Mucha J., Witkowski W.: The clinching joints strength analysis in the aspects of changes in the 
forming technology and load conditions. ThinWalled Structures 82, 2014, 55-66.

5. Cacko R., Czyżewski P.: Numeryczne modelowanie kształtowania i obciążania połączeń nitowanych bezotworowo. Przegląd mechaniczny, 7-8, 2005, 50-53.

6. He X., Zhao L., Yang H., Xing B., Wang Y., Deng Ch., Gu F., Ball A.: Investigations of strength and energy absorption of clinched joints. Computational Materials Science, 94, 2014, 58-65.

7. Mucha J.: The analysis of lock forming mechanism in the clinching joint. Materials and Design, 32, 2011, 4943-4954.

8. Coppieters S., Lava P., Baes S., Sol H., Van Houtte P., Debruyne D.: Analytical method to predict the pull-out strength of clinched connections. ThinWalled Structures, 52, 2012, 42-52.

9. Oudjene M., Ben-Ayed L., Delamézière A., Batoz J.-L.: Shape optimization of clinching tools using the response surface methodology with Moving Least-Square approximation. Journal of Materials Processing Technology, 209, 2009, 289-296.

10. Kaščák L., Spišák E.: Clinching as a non-standard method for joining materials of dissimilar properties. Zeszyty Naukowe Politechniki Rzeszowskiej, Mechanika, RUTMech, 3/84 (2012), 31-41.

11. Witkowski W.: Wytrzymałość okrągłych połączeń przetłoczeniowych typu clinching podczas próby ścinania i rozrywania. Czasopismo Naukowe Mechanik, 12, 2014, 990-992.

12. Markowski T., Mucha J. Witkowski W.: Eksperymentalna analiza wytrzymałości okrągłych połączeń przetłoczeniowych formowanych jednolitą matrycą. Wybrane zagadnienia i problemy z zakresu budowy maszyn - cz.1. Oficyna Wydawnicza Politechniki Rzeszowskiej 2014, 99-110.

13. Mucha J., Witkowski W: Eksperymentalna analiza wytrzymałości okrągłych połączeń przetłoczeniowych blach ze stopu aluminium EN AW-5754 w stanie O/H111 poddanych złożonemu stanowi obciążenia. Przegląd Mechaniczny 2, 2015, 21-24.

14. Lambiase F., Di Ilio A.: Finite element analysis of material flow in mechanical clinching with extensible dies. Journal of Materials Engineering and Performance, 2(6), 2013, 1629-1636.

15. He X., Liu F., Xing B., Yang H., Wang Y., Gu F., Ball A.: Numerical and experimental investigations of extensible die clinching. The International Journal of Advanced Manufacturing Technology, 74(9-12), 2014, 1229-1236.

16. ISO 12996-2013 Mechanical joining - Destructive testing of joints - Specimen dimensions and test procedure for tensile shear testing of single joints.

17. http://www.tox-pl.com (01.01.2015). 